\title{
Experimental Investigation of Removal of Flue Gas Emissions Exhaust from Municipal Solid Waste Incinerator using Photo-Voltaic based Electrostatic Precipitator
}

Anandhraj Pannerselvam

Veltech Multitech Dr. Rangarajan Dr. Sakunthala Engineering College

Mohana Sundaram Kuppusamy

KPR Institute of Engineering and Technology

Jayaraman Shanmugapriyan

Veltech Multitech Dr. Rangarajan Dr. Sakunthala Engineering College

Vishnu Kumar Kaliappan

KPR Institute of Engineering and Technology

Prof. Dr. Ravishankar Sathyamurthy ( $\nabla$ raviannauniv23@gmail.com )

KPR Institute of Engineering and Technology https://orcid.org/0000-0002-2881-3455

\section{Research Article}

Keywords: Incineration, Electrostatic Precipitator (ESP), Flue Gas, Emissions, Photo Voltaic (PV), Stack sampler

Posted Date: June 11th, 2021

DOI: https://doi.org/10.21203/rs.3.rs-336756/v1

License: (c) (i) This work is licensed under a Creative Commons Attribution 4.0 International License. Read Full License 


\section{Abstract}

For the past decades, the flue gas emitted from Municipal Solid Waste Incinerator, Power Plant, and various industries are a permanent problem for the environment and has been affecting human life. Many flue gas filtration devices have been emerging out over the years. Although the Electrostatic Precipitator was an appropriate device due to high filtration efficiency, little pressure drop and energy efficiency, the cost and design of the Electrostatic Precipitator is a major restriction for manufacturers and end-users. With recent advances in technology,designing a cost-effective and less complex electrostatic precipitator has become mandatory. This article aims to design and develop a solar-powered costeffective Needle-Plate typeelectrostatic precipitator which includes a static power converters and high voltage Transformer-Rectifier (T-R) set with an input voltage as 230V AC, output voltage as 80kV Direct Current (DC) and output current of $40 \mathrm{~mA}$ for mitigation of Flue gas emissions exhaust from Municipal Solid Waste Incinerator. The analysis of flue gas at ESP inlet and outlet has been performed using Ecotech stack sampler and flue gas analyzer. The obtained experimental results are validated with Emission standards provided in the Solid Waste Management rules book-India 2016.

\section{Introduction}

Municipal Solid Waste (MSW) Management, a decisive factor in the direction of sustainable urban growth, includes characterization, storage, treatment, segregation, collection, and disposal of solid waste to reduce its harmful impact on the atmosphere (Kumar et al., 2009). The quantity of MSW enlarges in corresponding to economic growth, owing to extreme consumption (USEPA, 2002). Solid Waste is categorized into three types, namely degradable, partially degradable, and non-degradable materials and it is generally collected from streets (Arvind et al., 2008).Recently alldeveloping countries are paying more attention to MSW management because most people do not have enoughfacilities to utilize MSW storage service (Schubeler, 1996).As a result, proper management of MSW is significant for human health and the environment. In several countries, MSW is treated in three ways, such as incineration, landfilling, and recycling (USEPA, 2012).The incinerationmethod of treatment is cost-effective and ash produced from this treatment method canproduce expensive materials (Huang et al., 2006). The Primary advantage of incineration is the reduction of waste quantity,thereby space required for landfills is decreasedandprovides additional energy sources from ignition (Ornebjerg et al., 2006). The Incineration of MSW produces flue gases such as Carbon Dioxide $\left(\mathrm{CO}_{2}\right)$, CarbonMonoxide (CO), Particulate Matter (PM), $\mathrm{HCl}$, SulphurDioxide $\left(\mathrm{SO}_{2}\right)$, Nitrogen Oxide (NO), total organic carbon, $\mathrm{Hg}$ and its compounds (Alba et al., 1997; Quinaa et al., 2008). The burning of coal, coal processing waste and coal derivatives has produced various gas emissions, especially nitrogen and sulfur oxides are harmful. The percentage of harmful gases depends on the composition and concentration of coal, water, and flammable liquid. The results indicate that coal mixed with water producesfewer gas emissions compared to coal (Margarita et al., 2018).ESP has been utilized to remove emissions such as particulate matter, nitrogen oxide (NO), and carbon monoxide from the diesel exhaust(Phirun et al., 2012).Suppose the particulate matter in harmful gases is released into the atmosphere without a filtration system. In that case, it could cause climate change, affect human health, and also causelung diseases and bronchitis. Generally, an Electrostatic precipitator is one of the devices to purify the fine dust particles and smoke from flue gases. It has high collection efficiency, low energy consumption and pressure drop (Kim et al., 2001; Remaoun et al., 2014; Patino et al., 2016). In ESP, thehigh voltage power supplyrequires a range of 15 to $100 \mathrm{kV}$ for effective ultra-fine dust particle collection from flue gases (Grasset al., 2004;Shafiei et al., 2013; Slobodan et al., 2016). Researchers worldwide have published many articles pertaining to the augmentation of collection efficiency of ESP based on discharge electrode shape, material, inter discharge electrode distance, the distance between collecting plate and discharge electrode, and other parameters. The filtration efficiency of ESP hasbeen investigated for different discharge electrode positions using aerosol spectrometer GRIMM 1.109, which measures the particle concentration with a measuring range of 0.25 to $32 \mu \mathrm{m}$. The obtained results clearly indicate that position of the discharge electrode and 
polarity of DC voltage play a vital role in collection efficiency (Niewulis et al., 2011).The electrical characteristics of wireplate ESP, which is a function of discharge electrode geometry, inter discharge electrode distance, and the number of discharge wires, have been analyzed. The results have proved that electrical characteristics and ESP filtration efficiency are enhanced by reducing the collecting plate distance without increasing applied voltage (Khaled and Eldein, 2013). The collection efficiency, which is the ratio of dust particles deposited on the collection electrode and total dust particles entered into the ESP. Design of ESP requires accurate calculation of collection efficiency, which in turn requires total collection area, gas flow rate and dust particle migration velocity. The researchers investigated the important parameters for an ESP, which includes the shape of the discharge electrode, distance between two discharge electrodes, and discharge wire to collecting plate spacing, gas flow rate, and applied voltage at the discharge electrode(Narendra Gajbhiye et al., 2015). The simulation for two types of ESP, (i) ESP with Spike discharge electrode and, (ii) ESP with wire discharge electrode to investigate the particle collection efficiency and other geometries in the two types of ESP remain unchanged. High Voltage DC is applied to the spike electrode thereby corona is produced at the spike tips (S. Arif et al., 2016). Needle-plate electrostatic precipitator by changing design parameters such as radius of the needle tip, distance between needle and plate, applied voltage to the needle and temporal characteristics of trichel pulses. Needle-plane distance varies from $6 \mathrm{~mm}$ to $3 \mathrm{~cm}$, radius of the needle varies from $19 \mathrm{~mm}$ to $55 \mathrm{~mm}$ and applied voltage varied from $4 \mathrm{kV}$ to $-10 \mathrm{kV}$. The DC corona current and frequency of trichel pulse increases by increasing applied voltage and decreases by increasing needle-plate distance (Peyman Dordizadeh et al., 2016). The Comsol Multiphysics simulation for the gas flow (fluid dynamics) part is based on the Navier-stokes equation. For small diameter particles, the drag force is corrected by Cunningham correction factor, the second important force acting on the dust particle is Coulomb force which is based on the electric field and charged particle (Donato Rubinetti et al. 2015). The Electrostatic Precipitator collection efficiency is based on the gas flow rate, size of the precipitator, and particle migration velocity which is given by Deutsch-Anderson equation. The Reynolds number is a dimensionless number which helps to predict the fluid flow patterns. It is defined as the ratio of inertial force and viscous force. If the Reynolds number is less than or equal to 2000 then the flow is laminar. If the Reynolds number value is between 2000 to 4000 then the flow is transitional. If the Reynolds number value is greater than 4000 then the flow is turbulent (Dang Xiaoqing et al.). There are two ways of increasing the collection efficiency of ESP are (i) increase the dust particle migration velocity by maximizing the electric field strength around the discharge electrode (ii) by decreasing the gas flow rate (Octavian Blejan et al., 2007). The corona discharge electrode ESP is suitable to remove diesel exhaust particles. Still, it has low filtration efficiency for Nitrogen Oxide (NO). The barrier discharge electrode-based ESP is suggested to improve filtration efficiency for Nitrogen oxide (NO) as well as diesel particulate matter. The discharge electrode is made up of aluminum plates with a thickness of $0.5 \mathrm{~mm}$, and collecting plates are made up of glass. The experimental analysis is carried out with the help of Particle counter (RION model KC-01B, C) for barrier discharge electrode with and without the punched hole. The ESP Efficiency is determined based on the operating time, discharge power, and applied voltage. The results have been validated. It is found that the filtration efficiency of ESP is higher for large diameter punched electrodes than plane electrodes, and small diameter punched electrodes (Kuroda et al., 2003). The ESP filtration efficiency is enhanced with the help of foamcovered collecting electrodes. Dust Particles coming into the pores have not easily returned to the atmosphere, and also it reduces the pre and post filter in the ESP. The particle counter (Haltech HPC600) has been used to count the dust particles at ESP outlet, and the experiments have been carried out for different airflow velocities i.e. $0.5 \mathrm{~m} / \mathrm{sec}$ to 2.5 $\mathrm{m} / \mathrm{sec}$. The results have been validated and found that foam-covered collecting plates in ESP have higher collection efficiency and moderate airflow velocity, suitable for capturing small dust particles (Wen et al., 2015). Collection Efficiency of ESP has been analyzed based on the concentration of particles and found that high efficiency is achieved when inlet particle concentration ranges from $200 \mathrm{mg} / \mathrm{Nm}^{3}$ to $3600 \mathrm{mg} / \mathrm{Nm}^{3}$ (Arif et al., 2018).A wet dust removal system (WDRS) has been developed by using wet phase transition agglomerator (WPTA) and wet electrostatic precipitator (WESP). In a Coal-fired power plant, the emission of particles has reduced to less than $5 \mathrm{mg} / \mathrm{m}^{3}$ with the help of WDRS. The results clearly indicate that the filtration efficiency of the WESP has been increased by increasing the applied voltage(Cao et al., 2017). The removal of flue gas emission from Incinerator has been carried out in two ways (i) using 
after burners (ii) using a combined system. The experimental results clearly show that the concentration of dioxins (PCDDs + PCDFs) at inlet and outlet of after burner is $66.1 \mathrm{ng}-\mathrm{TEQ} / \mathrm{Nm}^{3}$ and $0.213 \mathrm{ng}-\mathrm{TEQ} / \mathrm{Nm}^{3}$, respectively. Further, the efficient dioxin decomposition has been achieved with the gas temperature greater than $850^{\circ} \mathrm{C}$. The combined wet type ESP system, scrubber, and radiator successfully remove gaseous pollutants and dusts such as dioxins (PCDDs + PCDFs) and $\mathrm{HCl}$ for a large range of initial concentrations. Besides, this system achieves more than $90 \%$ efficiency in any case of initial concentration (Kim et al., 2000). The elimination of $\mathrm{PM}_{2.5}$ particles has been done by using lab-scale two-stage electrostatic precipitator with precharge and parallel collecting plates. The analysis of collection efficiency for two-stage ESP is conducted with Alternating Current (AC) and DC voltages and found that $>96 \%$ and $>90 \%$ efficiency has been attained when the precharger was energized by DC and AC voltages, respectively (Jaworek et al., 2017). The flue gas cleaning method has been conducted using eight different Air Pollution Control (APC) technologies from no treatment to the most modern APC technology and found that wet flue gas cleaning, semidry flue gas cleaning and dioxin filter followed by flue gas condensation and Selective Catalytic Reduction (SCR) have provided the finest flue gas emission control mechanism. Apart from this, Electrostatic Precipitator and Fabric filter provides better removal efficiency (>95\%) for small and large particle size $(\mu \mathrm{m})$ compared with cyclone and low-pressure venture scrubber (Vehlow et al., 2010). The removal of particulate matter from a small waste incinerator's exhaust gas has been achieved with the pilotscale ESP with the sizing of $(1000 \mathrm{~mm} * 10000 \mathrm{~mm} * 1000 \mathrm{~mm})$. The results clearly indicate that $100 \%$ collection efficiency has been achieved with the particles larger than $400 \mathrm{~nm}$ (Intra et al., 2014). Hence considering the above facts, the intention of this paper is to design a cost-effective Photo-Voltaic powered Needle-plate Electrostatic Precipitator with dimensions $(900 \mathrm{~mm} \star 250 \mathrm{~mm})$ to filter the fine dust particles and smoke from flue gases produced by incineration of MSW.

\section{Materials And Methodology}

The needle-plate ESP has been preferred in this work because it can handle a higher gas flow rate and produce high electric field strength around the discharge electrode compared to other ESP types.The schematic diagram of the entire experimental setup is depicted in Fig. 1.The experimental setup consists of three parts such as (i) Power Supply to the Electrostatic Precipitator, (ii) Electrostatic Precipitator, (iii) Municipal Solid Waste Incinerator. In the Power Supply Part,A 250Wp PV module with maximum power point voltage $\left(\mathrm{V}_{\mathrm{mpp}}\right)$ of $37.15 \mathrm{~V}$ and maximum power point current of $7.29 \mathrm{~A}$ was given to the solar power conditioning unit, which consists of DC-DC Boost Converter and Voltage Source Inverter.

The DC voltage from the solar panel was stepped up and regulated by DC-DC Boost Converter, and the FGA25N120AN IGBT has been utilized in the inverter circuit to convert DC link voltage into AC with the switching time of 20 milliseconds. The 230V AC power supply is given as input to the T-R set, which converts 230V AC into (5-80) kV variable DCwith the help ofan electronic controller which is designed to adjust the output voltage and current of T-R set. The Electronic controller circuit consists of DSPIC33FJ128GP710A microcontroller, anti-parallel thyristors, voltage sensor, and current sensor. By adjusting thyristors' duty cycle, the primary winding voltage is varied, and thereby, secondary winding voltage is changed accordingly. The negative terminal of the T-R set is connected to the discharge electrode of the electrostatic precipitator,whereas the positive terminal is connected to the collecting plate, and it is grounded. The dimension of the Proposed Needle-Plate Electrostatic Precipitator is given in Table 1. 
Table 1

Design parameters and its values of the proposed Electrostatic Precipitator

\begin{tabular}{|ll|}
\hline Design Parameters & Values \\
\hline Gas Flow Rate & $0.56 \mathrm{cu} . \mathrm{m} / \mathrm{sec}$ \\
\hline Pressure Drop & $20 \mathrm{~mm}$ of WG \\
\hline Temperature & $150^{\circ} \mathrm{C}(\mathrm{max})$ \\
\hline Inlet and outlet diameter of the ESP & $200 \mathrm{~mm}$ \\
\hline Length of the collecting plate & $1830 \mathrm{~mm}$ \\
\hline Breadth of the collecting plate & $1735 \mathrm{~mm}$ \\
\hline Distance between two collecting plates & $200 \mathrm{~mm}$ \\
\hline Radius of the discharge electrode & $0.75 \mathrm{~mm}$ \\
\hline Distance between discharge electrodes & $200 \mathrm{~mm}$ \\
\hline Distance between discharge electrode and collecting plate & $100 \mathrm{~mm}$ \\
\hline
\end{tabular}

The discharge electrode is made up of stainless steel (SS 302), which has higher carbon than other grades and does not corrode easily. The Collecting Plates, Carcass of ESP, inlet, and outlet duct is designed using mild steel. The collecting plates are connected to the outer structure of the Electrostatic Precipitator, and it is earthed. The discharge electrodes are connected to the high voltage power supply, and it is isolated from the ESP body using a Teflon insulator. High Voltage DC is slightly varied from $5 \mathrm{kV}$, and the negative gradient of the electric field is also increased accordingly. When applied voltage attains the corona onset voltage, Corona current starts flowing from discharge electrode to collecting plate which ionizes the flue gases produced within a specially designed Incinerator by burning MSW. Liquefied Petroleum Gas (LPG) has been used as fuel in the incinerator. Exhaust Fan is located downstream of the ESP to collect the flue gas from incinerator through Electrostatic Precipitator. The experimental setup entire system is depicted in Fig. 2.Flue gas analysis has been performed at ESP inlet and outlet using stack sampler and flue gas analyzer. The sampling process has been conducted for thirty minutes. The sampling porthole has a diameter of $76.2 \mathrm{~mm}$, which helps to place the gas analyzer probe and sampling thimble from the stack sampler.

\section{Results And Its Discussion}

The magnitude of the $\mathrm{V}_{\mathrm{DC}}$ limit has been manually set in the electronic controller. It clearly indicates that ESP voltage is varied based on the transformer primary winding Voltage. The transformer rectifier's output voltage has been reached $78.9 \mathrm{kV}$ DC for the transformer primary winding voltage of $199 \mathrm{~V}$ AC. The current-voltage characteristic of the developed Electrostatic Precipitator is depicted in Fig. 3.

The flow chart depicts the system boundary for the filtration efficiency of ESP analysis (Fig. 4). The DC voltage applied to the Electrostatic Precipitator can be controlled from the electronic controller of the Transformer-Rectifier (TR) set.

The corona current has started at the corona inception voltage of $10 \mathrm{kV}$; after that, it has been varied linearly with applied voltage.The electric field intensity has been analyzed numerically for ESP with different distances between needle and collecting plate. It clearly indicates in the Fig. 5 that impact of varying distance between the needle electrode and collecting plate (a) has changed the magnitude of electric field intensity. An electric field's strength is high at the tip of the needle, and it decreases as distance increases from the discharge electrode to the collecting plate. 
The filtration efficiency of ESP is mainly based on electric field intensity, and thereby high efficiency is achieved with a smaller distance between the needle and collecting plate. Thus, a $0.1 \mathrm{~m}$ distance has been maintained between needletype emitting electrode and collecting plate in this work. The Poissonian electric field has been applied to describe Fig. 6 , which is given in Eq. (1)

$$
\nabla \cdot \mathrm{E}=\rho / \epsilon_{0}
$$

1

Where E- Electric Field Intensity, $\rho$-Space Charge Density, $\varepsilon_{0}$ - relative permittivity. The collection efficiency for different particle diameter concerningto applied voltage is depicted in Fig. 6. From the graph, we can observe that particle collection efficiency is $65 \%$ for the applied voltage of $24 \mathrm{kV}$ with the particle diameter of $5 \mu \mathrm{m}$. However, with the same applied voltage, the particle collection efficiency is $55 \%$ and $41 \%$ for the dust particle diameter of $3 \mu \mathrm{m}$ and $2 \mu \mathrm{m}$, respectively. Thus, the collection efficiency of the ESP is directly related to the diameter of the dust particle. Further, with the help of the graph, we can conclude that the collection efficiency of ESP is increasing with respect to the applied voltage.

A stack sampler is used to collect the gas from the inlet and ESP outlet to measure the PM concentration. After the gas is collected, PM concentration is obtained by using the weight of a sampling thimble. The mathematical calculation of PM concentration is represented in the Eqs. (2) and (3)

$$
\operatorname{PM}\left(\mathrm{mg} / \mathrm{Nm}^{3}\right)=\left((\mathrm{A}-\mathrm{B}) * 10^{6}\right) / \mathrm{C}
$$

2

$$
\mathrm{C}=\left(\mathrm{E}^{*} \mathrm{~T}\right) / \mathrm{D}
$$

3

Where A-Initial weight of the thimble, B-Final weight of the thimble, $\mathrm{C}=$ Air volume in $\mathrm{m}^{3}$, E-Volume of Liters Per Minute (LPM), D-Volume of air in liters, T-Sampling time. The Flue gas analyzer measures the CO, NOin parts per million. The Conversion of parts per million into $\mathrm{mg} / \mathrm{Nm}^{3}$ is given in the Eq. (4)

$$
\mathrm{mg} / \mathrm{Nm}^{3}=\left(\frac{\mathrm{PPM}^{*} \mathrm{M}}{\mathrm{D}}\right) *\left(\frac{\mathrm{P}}{\mathrm{P}_{0}}\right) *\left(\frac{\mathrm{T}}{\mathrm{T}_{0}}\right)
$$

4

Where PPM-Parts per Million, M-Molecular weight, P-Sea level pressure, T-Stack temperature, Standard pressure $\left(P_{0}\right)$-760 $\mathrm{mm} \mathrm{Hg}$, and Standard temperature $\left(T_{0}\right)-273.15 \mathrm{~K}$.Several countries have framed rule books enclosing information for emission standards. Table. 2 clearly indicates that all parameters at the ESP outlet fall within the emission standards laid down inthe SWM rules book by the Ministry of Environment, Forest, and Climate Change, Govt. of India [25] and the statistical analysis of Particulate Matter, Carbon Monoxide, and Nitrogen Oxide have been done with error assessments. 
Table 2

Test report of flue gas analysis at ESP inlet \& outlet with error assessments and emission standards

\begin{tabular}{|lllll|}
\hline $\begin{array}{l}\text { S. } \\
\text { No }\end{array}$ & Parameters & ESP inlet & ESP outlet & $\begin{array}{l}\text { Emission standards provided in the Solid Waste } \\
\text { Management rules book }\end{array}$ \\
\hline 1 & $\begin{array}{l}\text { Particulate } \\
\text { Matter }\end{array}$ & $\begin{array}{l}76.15 \pm \\
2 \mathrm{mg} / \mathrm{Nm}^{3}\end{array}$ & $\begin{array}{l}3.7 \pm 1 \\
\mathrm{mg} / \mathrm{Nm}^{3}\end{array}$ & $50 \mathrm{mg} / \mathrm{Nm}^{3}$ \\
2 & $\begin{array}{l}\text { Carbon } \\
\text { Monoxide }\end{array}$ & $\begin{array}{l}185 \pm \\
2 \mathrm{mg} / \mathrm{Nm}^{3}\end{array}$ & $\begin{array}{l}91.3 \pm \\
2 \mathrm{mg} / \mathrm{Nm}^{3}\end{array}$ & $100 \mathrm{mg} / \mathrm{Nm}^{3}$ \\
3 & $\begin{array}{l}\text { Total Organic } \\
\text { Carbon }\end{array}$ & $8 \pm 2$ & $3.21 \pm 2$ & $20 \mathrm{mg} / \mathrm{Nm}^{3}$ \\
& $\begin{array}{l}\text { Nitrogen } \\
\text { dioxide }\end{array}$ & $56 \pm 2$ & $\mathrm{mg} / \mathrm{Nm}^{3}$ & \\
& $\mathrm{mg} / \mathrm{Nm}^{3}$ & $\mathrm{mg} / \mathrm{Nm}^{3}$ & $400 \mathrm{mg} / \mathrm{Nm}^{3}$ \\
\hline
\end{tabular}

The flue gas emission test has been done for the concentration of Particulate Matter((PM2.5 \&PM10) at Electrostatic Precipitator outlet. The obtained results were $28 \mathrm{mg} / \mathrm{Nm} 3 \& 31 \mathrm{mg} / \mathrm{Nm} 3$ (Fig .7), which are found to be a little amount, and the permissible Emission standards provided in the Bio-Medical Waste Management rule book is $50 \mathrm{mg} / \mathrm{Nm} 3$.

Further, the filtration efficiency of ESP has been validated with the polyester filter samples, which are fixed upstream and downstream of the ESP, and it is depicted in Fig. 8(a, b). As anticipated, the color of the filter sample used to capture the smoke particles, alter depending on their location. The filter sample has been recovered a large quantity of dust particles before the ESP, which considerably changes its color. After the ESP, the filter sample color is not changed because the dust particles are deposited in the Collecting plate of ESP. The Collecting Plate after gas treatment is shown in Fig. 8c. It is noticed thata large amount of smoke particles are deposited in the plate after the ESP operation.

In addition to the experimental investigation of ESP, a CFD Modeling has been done to analyze the dust particle charging and its collection process in Electrostatic Precipitator. Numerical calculations were conducted for various applied voltages in the range of $45-90 \mathrm{kV}$ and various particle diameters in the range of $2 \mu \mathrm{m}-5 \mu \mathrm{m}$. The temperature and pressure were $293 \mathrm{~K}$ and 1 atmosphere, respectively. The dust particles with different diameters are entered into the Needle-Plate ESP inlet, and then it is charged and deposited on the collecting plates by an electrostatic field. In this case, 180 dust particles are entered, and then the performance of needle-plate ESP is analyzed for different applied voltage and particle diameters. 
Table 3

Comparison of dust particle entered and escaped with various diameter and applied voltage

\begin{tabular}{|c|c|c|c|c|c|c|}
\hline \multirow{2}{*}{$\begin{array}{l}\text { Applied } \\
\text { Voltage }\end{array}$} & \multicolumn{2}{|c|}{$2 \mu \mathrm{m}$ dust particle } & \multicolumn{2}{|c|}{$3 \mu \mathrm{m}$ dust particle } & \multicolumn{2}{|c|}{$5 \mu \mathrm{m}$ dust particle } \\
\hline & $\begin{array}{l}\text { Number of } \\
\text { Particles } \\
\text { Entered }\end{array}$ & $\begin{array}{l}\text { Number of } \\
\text { Particles } \\
\text { Escaped }\end{array}$ & $\begin{array}{l}\text { Number of } \\
\text { Particles } \\
\text { Entered }\end{array}$ & $\begin{array}{l}\text { Number of } \\
\text { Particles } \\
\text { Escaped }\end{array}$ & $\begin{array}{l}\text { Number of } \\
\text { Particles } \\
\text { Entered }\end{array}$ & $\begin{array}{l}\text { Number of } \\
\text { Particles } \\
\text { Escaped }\end{array}$ \\
\hline$-30 k V$ & 180 & 172 & 180 & 163 & 180 & 94 \\
\hline$-45 k V$ & 180 & 153 & 180 & 118 & 180 & 0 \\
\hline$-60 k V$ & 180 & 128 & 180 & 20 & 180 & 0 \\
\hline$-75 \mathrm{kV}$ & 180 & 87 & 180 & 0 & 180 & 0 \\
\hline$-90 k V$ & 180 & 21 & 180 & 0 & 180 & 0 \\
\hline$-95 k V$ & 180 & 6 & 180 & 0 & 180 & 0 \\
\hline
\end{tabular}

With the help of Table 3, we can conclude that the performance of Needle-Plate ESP is excellent for large particle diameter with high applied voltage.

The collection efficiency of the proposed needle-plate type Electrostatic Precipitator is high compared to the other two methods.Compared with existing methods, the proposed method utilizes renewable energy sources; thereby, no external power supply is required.

Table 4

Comparison of developed work with two other methods

\begin{tabular}{|c|c|c|c|}
\hline $\begin{array}{l}\text { Dimensions and Operating } \\
\text { conditions }\end{array}$ & Work 1 & Work 2 & Developed Work \\
\hline Type of ESP & $\begin{array}{l}\text { Wire-Tube } \\
\text { type }\end{array}$ & Wire-Plate type & Needle-Plate type \\
\hline Number of Plates/Tubes & 19 & 10 & 7 \\
\hline Number of discharge electrodes & 19 & 10 per row & 54 \\
\hline Discharge electrode diameter & $2 \mathrm{~mm}$ & $3 \mathrm{~mm}$ & $1.5 \mathrm{~mm}$ \\
\hline $\begin{array}{l}\text { Height or length of the collecting } \\
\text { electrode }\end{array}$ & $400 \mathrm{~mm}$ & $1000 \mathrm{~mm}$ & $1830 \mathrm{~mm}$ \\
\hline $\begin{array}{l}\text { Distance between collection plate } \\
\text { to discharge electrode }\end{array}$ & $10.77 \mathrm{~mm}$ & $50 \mathrm{~mm}$ & $100 \mathrm{~mm}$ \\
\hline $\begin{array}{l}\text { Distance between discharge } \\
\text { electrodes }\end{array}$ & - & $50 \mathrm{~mm}$ & $200 \mathrm{~mm}$ \\
\hline Operating Voltage & $6-8 \mathrm{kV}$ & $20 \mathrm{kV}$ & $55 \mathrm{kV}$ \\
\hline Collection Efficiency & $\sim 70$ & $\sim 80$ & $\sim 86.7$ \\
\hline Source for Power Supply to the ESP & $\begin{array}{l}\text { 220V AC } \\
\text { power supply }\end{array}$ & $\begin{array}{l}220 \mathrm{~V} \text { AC power supply or } 12 \mathrm{~V} \\
\text { Battery or solar cells }\end{array}$ & $\begin{array}{l}\text { Solar power with } \\
\text { backup } 12 \mathrm{~V} \text { batteries }\end{array}$ \\
\hline Reference & $\begin{array}{l}\text { (Intra et al., } \\
2010)\end{array}$ & (Intra et al., 2014) & - \\
\hline
\end{tabular}




\section{Energy And Cost Savings In Comparison To Conventional System}

The emissions or waste from the electricity produced by Solar panels would be zero (Table. 5). In contrast to, fossil fuels, power plants, Solar Panel can produce clean and renewable energy without locating, excavation, transportation, or combustion. It's a simpler, cheaper, cleaner, and all-around better energy solution.

Table 5

Comparison of conventional and solar powered ESP

\begin{tabular}{|c|c|c|}
\hline & Conventional Electricity to ESP & Solar Powered ESP \\
\hline $\begin{array}{l}\text { Fuel } \\
\text { Sourcing }\end{array}$ & $\begin{array}{l}\text { Fossil fuels must be situated, digged } \\
\text { out and transported before it came to } \\
\text { the usage. These activities would make } \\
\text { the land most instability. }\end{array}$ & $\begin{array}{l}\text { Energy from the sun is harmless and free. It can be } \\
\text { harnessed and converted into power anyplace a solar } \\
\text { panel can be installed. }\end{array}$ \\
\hline $\begin{array}{l}\text { Power } \\
\text { Generation }\end{array}$ & $\begin{array}{l}\text { Fossil fuels need to be burned to } \\
\text { produce electricity, it would make air } \\
\text { pollution and other environmental } \\
\text { damage }\end{array}$ & Solar can produce power without emissions and waste. \\
\hline \multirow[t]{5}{*}{$\begin{array}{l}\text { Cost of } \\
\text { Consumer } \\
\text { Electricity }\end{array}$} & $\begin{array}{l}\text { Total number of Units required by } \\
\text { developed Electrostatic Precipitator per } \\
\text { day: } 4.8\end{array}$ & $\begin{array}{l}\text { Total Amount Spent for } 1000 \mathrm{Wp} \text { Solar power with four } \\
\text { backup batteries and solar power conditioning unit: Rs. } \\
1,72,000\end{array}$ \\
\hline & $\begin{array}{l}\text { Total number of Units required per year: } \\
1752\end{array}$ & Total Savings: Rs.90800 (Rs.262800- Rs. 1,72,000) \\
\hline & $\begin{array}{l}\text { Total number of Units required for } 25 \\
\text { years: } 43800\end{array}$ & \\
\hline & EB cost for 1 unit in India: Rs. 6 & \\
\hline & $\begin{array}{l}\text { EB cost for total number of units } \\
\text { required for } 25 \text { years: Rs. } 262800\end{array}$ & \\
\hline $\begin{array}{l}\text { The Human } \\
\text { Element }\end{array}$ & $\begin{array}{l}\text { The availability of Fossil fuels has been } \\
\text { decreasing over the years. It can lead to } \\
\text { labor strikes, price volatility, and even } \\
\text { war. }\end{array}$ & $\begin{array}{l}\text { The availability of Solar energy is abundant and it will be } \\
\text { accessible for another } 5 \text { billion years }\end{array}$ \\
\hline $\begin{array}{l}\text { Transformer- } \\
\text { Rectifier }\end{array}$ & $\begin{array}{l}\text { (i) The } 50 \mathrm{~Hz} \text { Transformer-Rectifier set is } \\
\text { large and it would produce voltage } \\
\text { ripples in the range of } 30 \text { to } 40 \% \text { of } \\
\text { output } \mathrm{DC} \text { voltage. It requires more time } \\
\text { to treat the dust particle coming out of } \\
\text { Electrostatic Precipitator. }\end{array}$ & $\begin{array}{l}\text { (i) High frequency transformer operated with } 20 \mathrm{KHz} \text { to } \\
1 \mathrm{MHz} \text {. Size of this transformer is less and it would } \\
\text { produce small ripple in the output DC voltage. HF } \\
\text { Transformer - Rectifier provides higher and average } \\
\text { power supply into the ESP thereby time needed to treat a } \\
\text { particle can be much shorter. This in }\end{array}$ \\
\hline
\end{tabular}

\section{Conclusion}

This proposed article has identified the potential ways to design and implement cost-effective solar-powered electrostatic precipitators for the filtration of flue gases from Municipal Solid Waste Incinerators. The ESP has been energized by solar energy with power electronic converters and a high voltage T-R set. The flue gas analysis of ESP has been carried out with a stack sampler and flue gas analyzer. The obtained results for particulate matter, carbon monoxide, and other flue gases have been validated and found that it falls within the required emission standards. Further, the collection efficiency of ESP has been validated with a polyester filter sample. Near future, we planned to conduct flue gas analysis for all the major pollutants released from the incineration of Municipal Solid Waste (MSW) with the help of pilot-scale ESP with the dimensions of $(2740 \mathrm{~mm} \times 1310 \mathrm{~mm})$. 


\section{Declarations}

\section{Competing interest}

The authors declare that there is no competing interest

\section{Availability of data and materials}

Not Applicable

\section{Ethical Approval}

Not Applicable

\section{Consent to Participate}

Not Applicable

Consent to Publish

Not Applicable

\section{Authors Contributions}

Conceptualization, Methodology, Resources, Formal analysis and investigation were carried out by Anandhraj Pannerselvam, Mohana Sundaram Kuppusamy, Jayaraman Shanmugapriyan, Vishnu Kumar Kaliappan, Ravishankar Sathyamurthy

\section{Funding}

This work was financially supported by DST-Technology Systems Development Programme (No.DST/TSG/WM/2015/557/G) Government of India.

\section{References}

Alba, N., Gasso, S., Lacorte, T., Baldasano, J.M., 1997. Characterization of Municipal Solid Waste incineration residues from facilities with different Air Pollution Control systems. Journal of the Air \& Waste Management Association. 47, 1170-1179. https://doi.org/10.1080/10473289.1997.10464059.

Arif, S., Branken, D.J., Everson, R.C., Neomagus, H.W.J.P., Arif, A., 2018. The influence of design parameters on the occurrence of shielding in multi electrode ESPs and its effect on performance. Journal of Electrostatics. 93, 1730. https://doi.org/10.1016/j.elstat.2018.03.001.

Arif, S., Branken, D.J., Everson, R.C., Neomagus, H.W.J.P., le Grange, L.A., Arif, A., 2016. CFD modeling of particle charging and collection in electrostatic precipitators. Journal of Electrostatics. 84 10-22.

https://doi.org/10.1016/j.elstat.2016.08.008

Arvind, K..J., Sharma, C., Singh. N., Ramesh. R., Purvaja, R., Gupta, P.K., 2008. Greenhouse gas emissions from municipal solid waste management in Indian mega-cities: A case study of Chennai landfill sites. Chemosphere. 71, 750-758. https://doi.org/10.1016/j.chemosphere.2007.10.024. 
Cao, R., Tan, H., Xiong, Y., Mikulčić, H., Vujanović, M., Wang, X., Duić, N., 2017. Improving the removal of particles and trace elements from coal-fired power plants by combining a wet phase transition agglomerator with wet electrostatic precipitator. Journal of Cleaner Production. https://doi.org/10.1016/j.jclepro.2017.05.046.

Chin-Ming Huang, Wan-FaYang, Hwong-Wen Ma, Yii-RenSong, 2006. The potential of recycling and reusing municipal solid waste incinerator ash in Taiwan. Waste Management. 26, 979-987.https://doi.org/10.1016/j.wasman.2005.09.015.

Dang, Xiaoqing., Hongsheng, Hu., Guangda, Ma., Yan, Dongjie. Study and Application of Numerical Calculation Method for Gas Flow Distribution of Large Scale Electrostatic Precipitator. 11th International Conference on Electrostatic Precipitation.

Donato, Rubinetti., Daniel, A, Weiss., Walter, Egli.,2015. Electrostatic Precipitators - Modelling and Analytical Verification Concept. Comsol Conference. 14-16.

Grass, N., Hartmann, W., Klockner, M., 2004. Application of different types of high-voltage supplies on industrial electrostatic precipitators. IEEE Trans. Ind. Applications. 40, 1513-1520.https://doi.org/10.1109/TIA.2004.836298.

Henrik ornebjerg, Jörn Franck, FransLamers, Francis Angotti, Robert Morin, Martin Brunner, 2006. Management of Bottom Ash from WTEPlants. International Solid Waste

Association.https://www.iswa.org/uploads/tx_iswaknowledgebase/Bottom_ash_from_WTE_2006_01.pdf.

Intra, P., Yawootti, A., Tippayawong, N., 2010. Particulate emission reduction from biomass burning in small combustion systems with a multiple tubular electrostatic precipitator. Particulate Science and Technology. 28, 547-

565. https://doi.org/10.1080/02726351003758444.

Intra, P., Yawootti, A., Tippayawong, N., 2014. Demonstration of a modular electrostatic precipitator to control particulate emissions from a small municipal waste incinerator. Journal of Electrical Engineering and Technology. 239246.https://doi.org/10.5370/JEET.2014.9.1.239.

Jaworek, A., Marchewicz, A., Sobczyk, A.T., Krupa, A., Czech T., 2017. Two-stage electrostatic precipitator with dualcorona particle precharger for PM2.5 particles removal. Journal of Cleaner Production.

https://doi.org/10.1016/j.jclepro.2017.07.032.

Khaled, U., Eldein, A.Z., 2013. Experimental study of V-I characteristics of wire-plate electrostatic precipitators under clean air conditions. Journal of Electrostatics. 71, 228-234. https://doi.org/10.1016/j.elstat.2012.12.023.

Kim, H.H., Yamamoto, I., Takashima K., Katsura, S., Mizuno A., 2000. Incinerator flue gas cleaning using wet-type electrostatic precipitator. Journal of Chemical Engineering of Japan. 33, 669-674. https://doi.org/10.1252/jcej.33.669.

Kim, S.H., Park, H.S., Lee, K.W., 2001. Theoretical model of electrostatic precipitator performance for collecting polydisperse particles. Journal of Electrostatics. 50,177-190. https://doi.org/10.1016/j.wasman.2007.08.030.

Kumar, S., Bhattacharyya, J.K., Vaidya, A.N, Chakrabarti, T., Devotta, S., Akolkar, A.B., 2009. Assessment of the status of municipal solid waste management in metro cities, state capitals, class I cities, and class II towns in India: An insight. Waste Management. 29, 883-895. https://doi.org/10.1016/j.wasman.2008.04.011.

Kuroda, Y., Kawada, Y., Takahashi, T., Ito, T., Zukeranb, A., Konob, Y., Yasumotob, K., 2003. Effect of electrode shape on discharge current and performance with barrier discharge type electrostatic precipitator. Journal of Electrostatics. 57,407-415.https://doi.org/10.1016/S0304-3886(02)00177-8. 
Margarita, A.D., Galina S.N., Pavel, A.S, 2018. Major gas emissions from combustion of slurry fuels based on coal, coal waste, and coal derivatives. Journal of Cleaner Production. 177, 284-301. https://doi.org/10.1016/j.jclepro.2017.12.254.

Ministry of Environment, Forest and Climate Change India, 2016. Solid Waste Management

Rules. http://www.moef.nic.in/content/so-1357e-08-04-2016-solid-waste-management-rules-2016?theme=moef_blue

Narendra, Gajbhiye., Eswaran, V., Saha, A.K., Anoop, Kumar.,2015. Numerical calculation of particle collection efficiency in an electrostatic precipitator. Sadhana. 40, 863-873. https://doi.org/10.1007/s12046-015-0342-1

Niewulis, A., Podliński, J., Shapoval, V., Mizeraczyk, J., 2011. Collection Efficiency in Narrow Electrostatic Precipitators with a Longitudinal or Transverse Wire Electrode. IEEE Transactions on Dielectrics and Electrical Insulation 18, 14231428.https://doi.org/10.1109/TDEl.2011.6032811.

Octavian, Blejan., Petru, V, Notingher., Laurentiu Marius Dumitran., Mohamed Younes., Adrian Samuila., Lucian Dascalescu., 2007. Experimental Study of the Corona Discharge in a Modified Coaxial Wire-Cylinder Electrostatic Precipitator. https://doi.org/10.1109/07IAS.2007.173.

Patino, D., Crespo, B., Porteiro, J., Villaravid, E., Granada, E., 2016. Experimental study of a tubular-type ESP for smallscale biomass boilers. Preliminary results in a diesel engine. Powder Technology. 288,164175.https://doi.org/10.1016/j.powtec.2015.11.006.

Peyman, Dordizadeh., Kazimierz, Adamiak., Peter Castle, G.S., 2016. Experimental study of the characteristics of Trichel pulses in the needle-plane negative corona discharge in atmospheric air. Journal of Electrostatics. 1-6. https://doi.org/10.1016/j.elstat.2016.12.013

Phirun, S., Keener, T.C., Mingming, L., Fuyan Liang, 2012. Control of Diesel Gaseous and Particulate Emissions with a Tube-Type Wet Electrostatic Precipitator.J. Air \& Waste Manage. Assoc.58,1311-1317. https://doi.org/10.3155/10473289.58.10.1311.

Quinaa, J.M., Bordado, J.C., Quinta-Ferreiraa, R.M., 2008. Treatment and use of air pollution control residues from MSW Incineration: An overview. Waste Management. 28, 2097-2121.

Remaoun, S.M., Zouzou, N., Tilmatine, A., Dascalescu, L., 2014. Optimization of a Cost-Effective “Wire-Plate” Type ESP for Installation in a Medical Wastes Incinerator. IEEE Transactions on Industry Applications. 50, 1391-1396. https://doi.org/ 10.1109/TIA.2013.2272607.

Schubeler, P., 1996. Conceptual Framework for Municipal Solid Waste Management in Low-Income Countries. http://www.academia.edu/1752446/Conceptual_framework_for_municipal_solid_waste_management_in_lowincome_countries.

Shafiei, N., Pahlevaninezhad, M., Farzanehfard, H., Bakhshai, A., Jain, P., 2013. Analysis of a fifth-order resonant converter for high-voltage dc power supplies. IEEE Trans. Power Electron. 28: 85100.https://doi.org/10.1109/TPEL.2012.2200301.

USEPA, 2012. Municipal Solid Waste (MSW) in the United States: Facts and Figures. https://archive.epa.gov/epawaste/nonhaz/municipal/web/html/msw99.html.

USEPA, 2002. What is Integrated Solid Waste Management?.https://nepis.epa.gov/Exe/ZyPURL.cgi? Dockey=P1000L3W.TXT. 
Vehlow, J., Dalager, S., 2010. Incineration: Flue Gas Cleaning and Emissions. Solid Waste Technology \& Management. 393-420. https://doi.org/10.1002/9780470666883.ch27.

Vukosavi, S.N., Peric, L.S., Susic, S.D., 2016. A Novel Power Converter Topology for Electrostatic Precipitators. IEEE Transactions on Power Electronics. 3, 152 -164.https://doi.org/10.1109/TPEL.2015.2405471.

Wen, T.Y., Wang, H.C., Krichtafovitch, I., Mamishev, A.V., 2015. Novel electrodes of an electrostatic precipitator for air filtration. Journal of Electrostatics. 73, 117-124. https://doi.org/10.1016/j.elstat.2014.11.002.

\section{Figures}

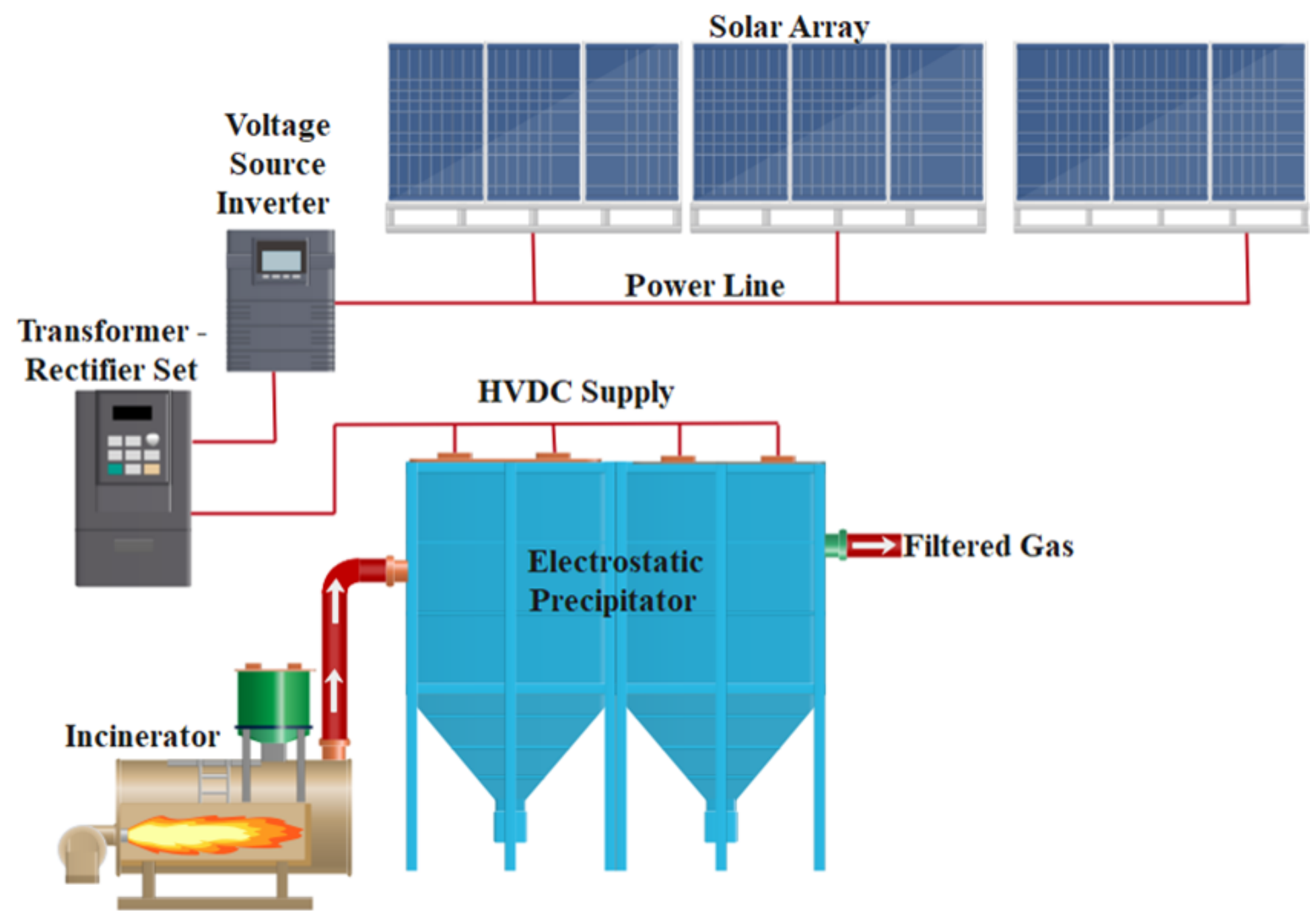

Figure 1

Schematic diagram of the experimental setup 


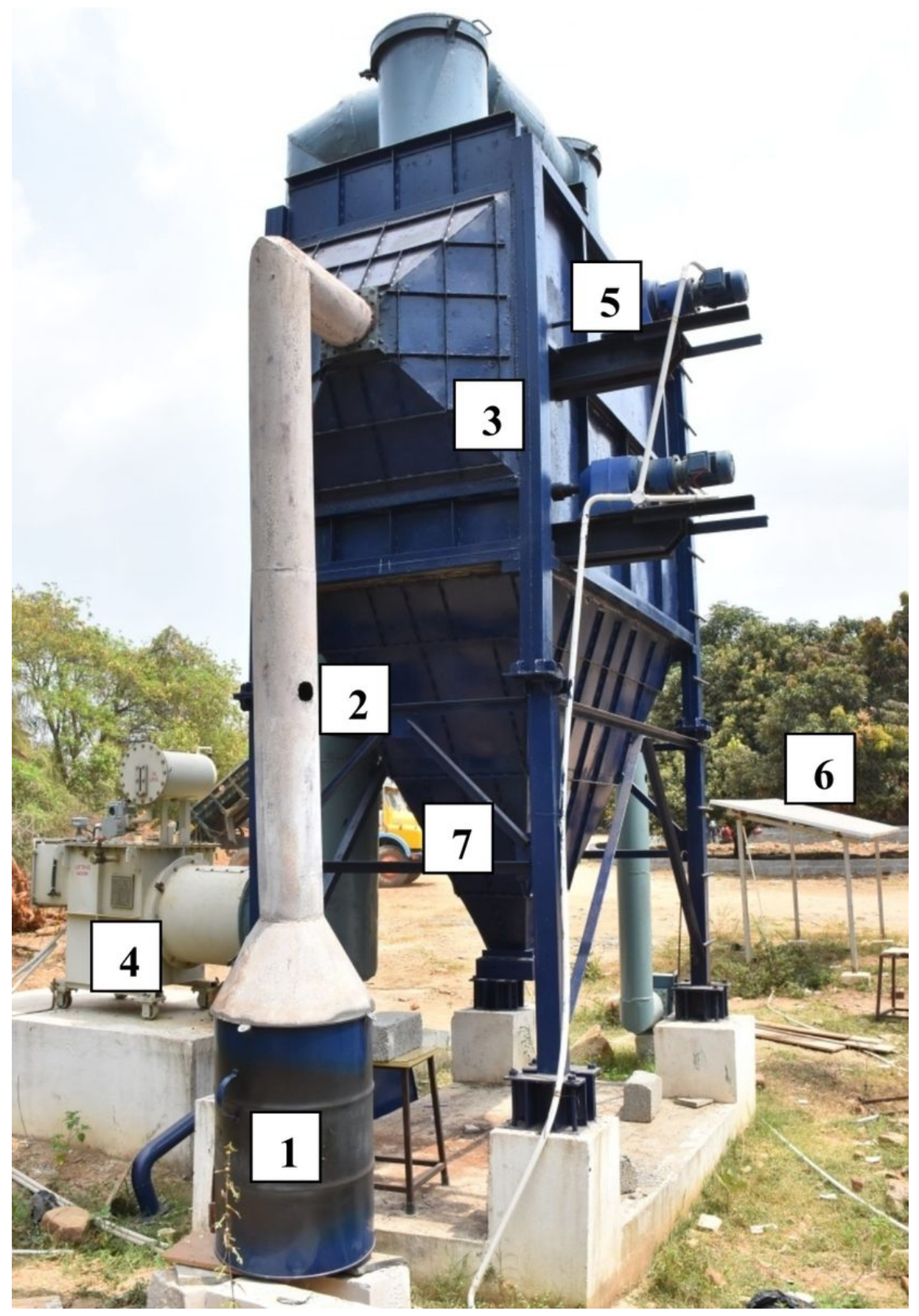

Figure 2

Experimental Set-Up. 1- Incinerator 2-Sampling Port Hole 3-ESP 4-TR Set 5-Rapper Motor 6-PV Array 7-Hopper 


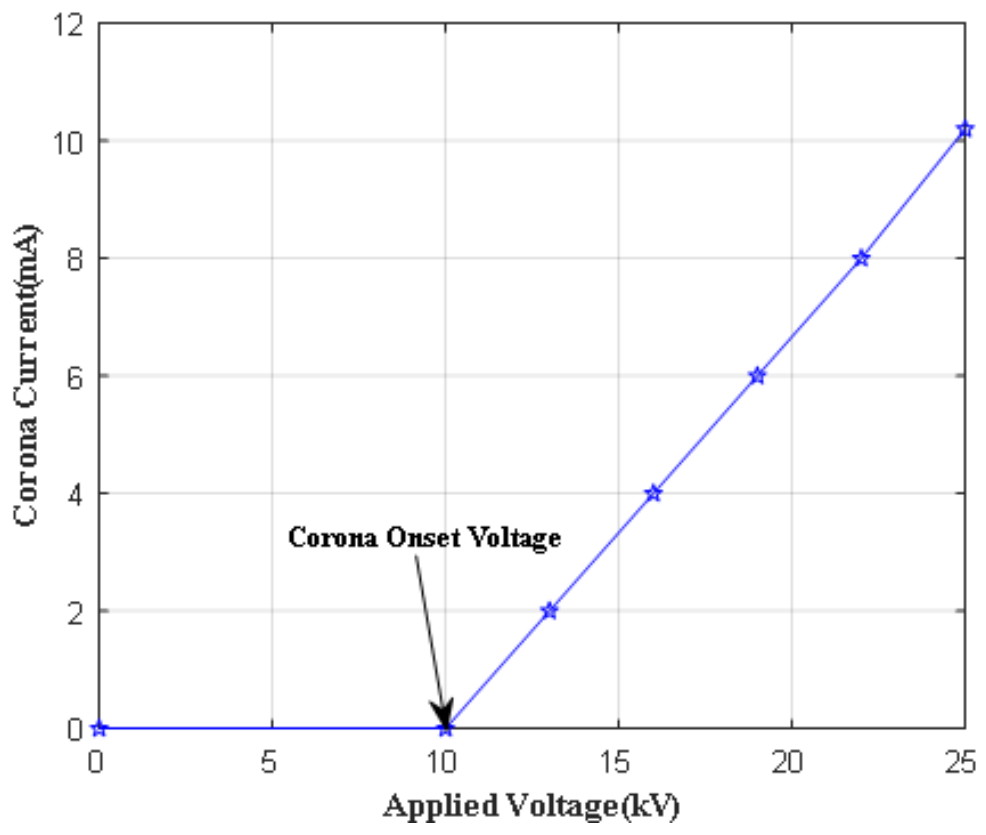

Figure 3

Voltage-Current characteristics of ESP

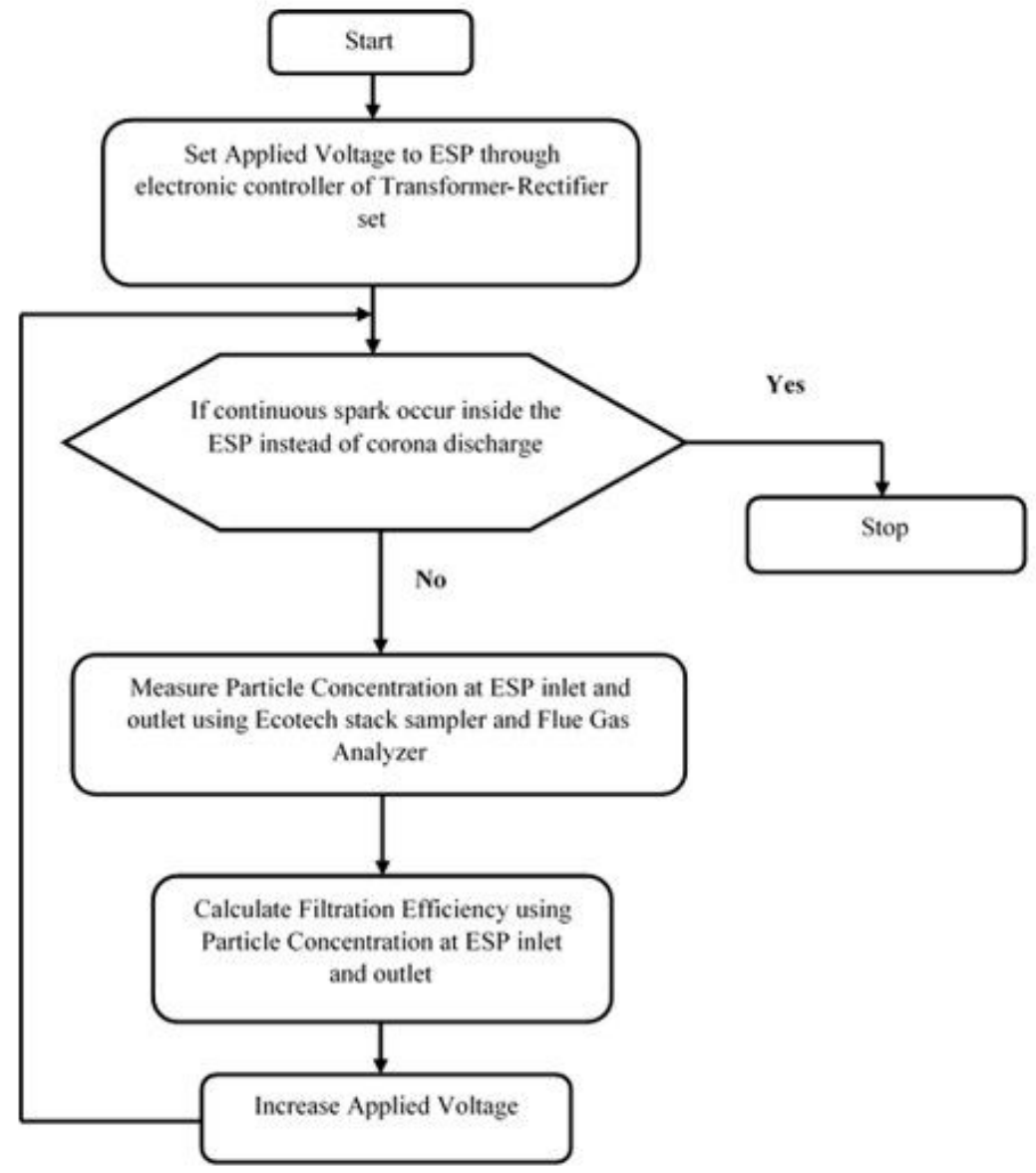

Figure 4

Flowchart for the filtration efficiency of ESP analysis 


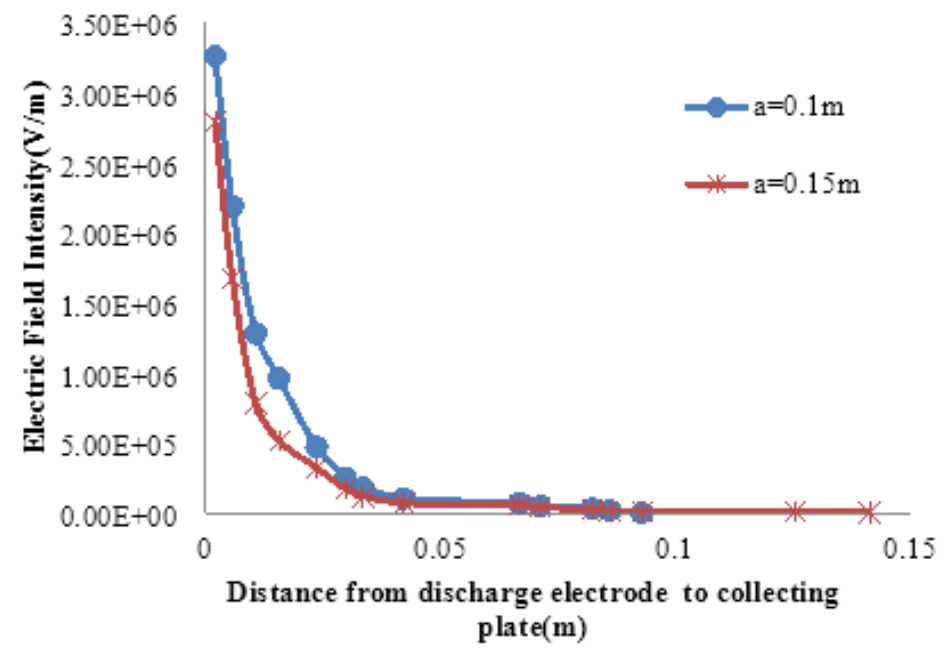

Figure 5

Electric Field Intensity as a function of the distance between the discharge electrode and the collecting plate.

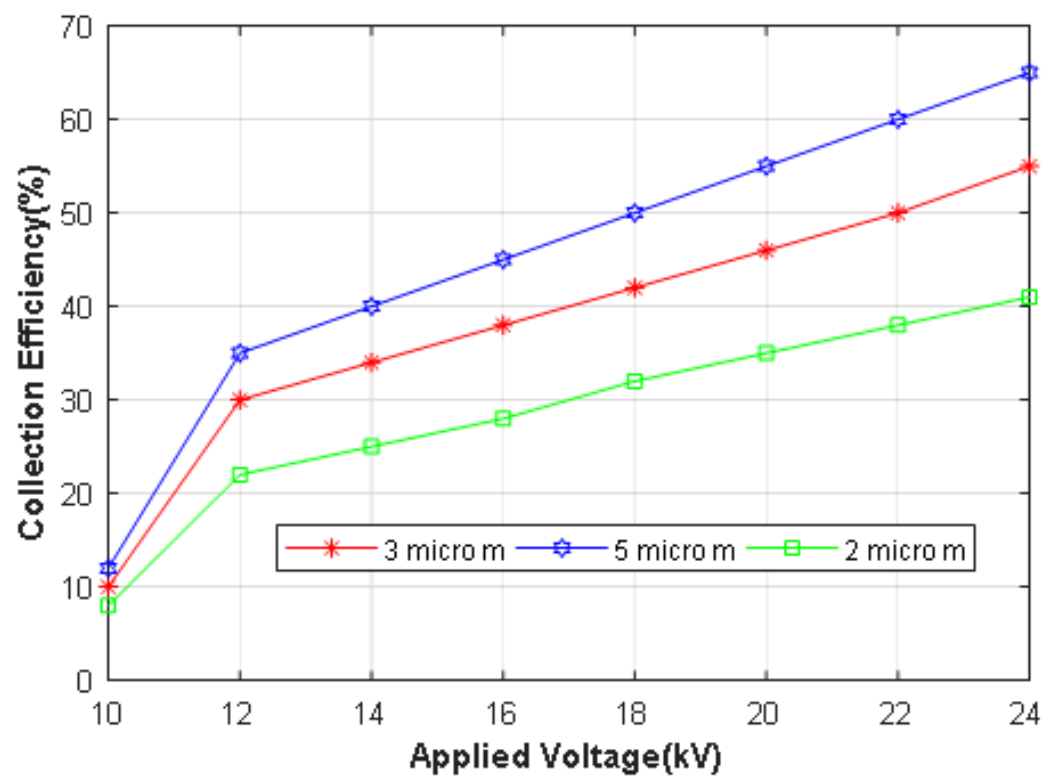

\section{Figure 6}

Influence of the voltage applied on the collection efficiency 


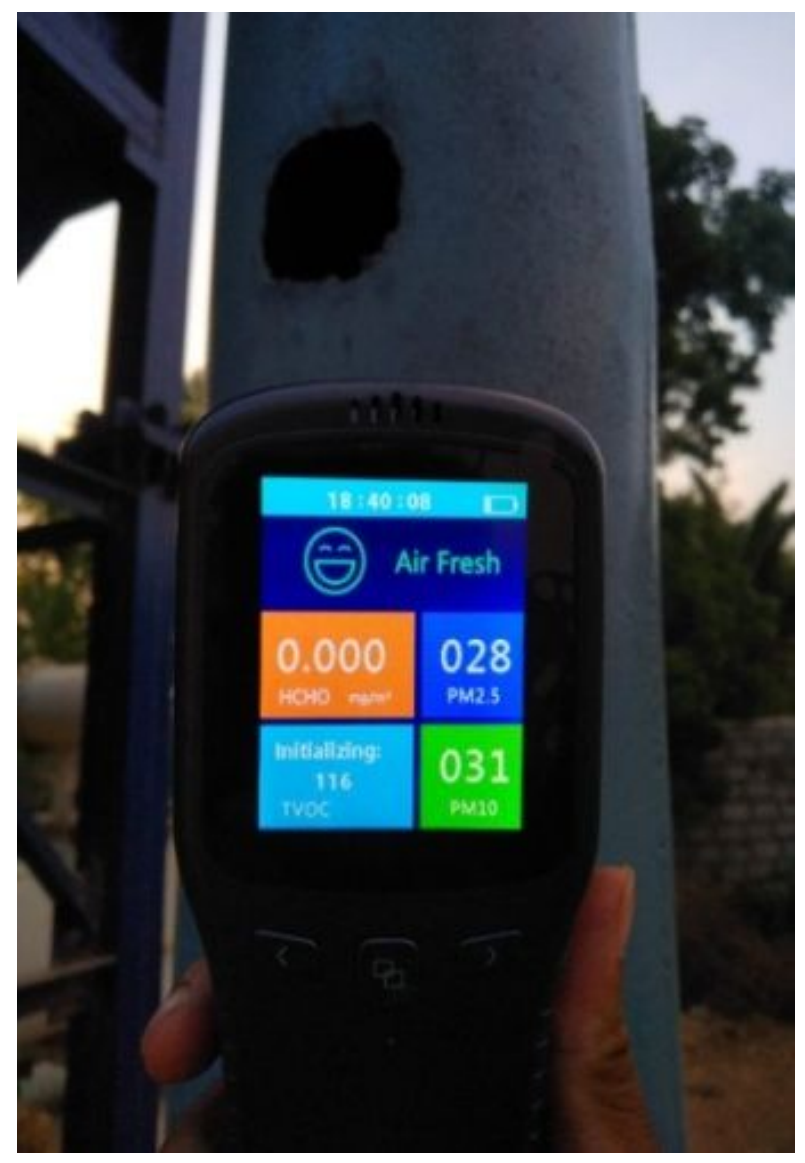

\section{Figure 7}

Particulate Matter (PM2.5 \& PM10) at ESP outlet
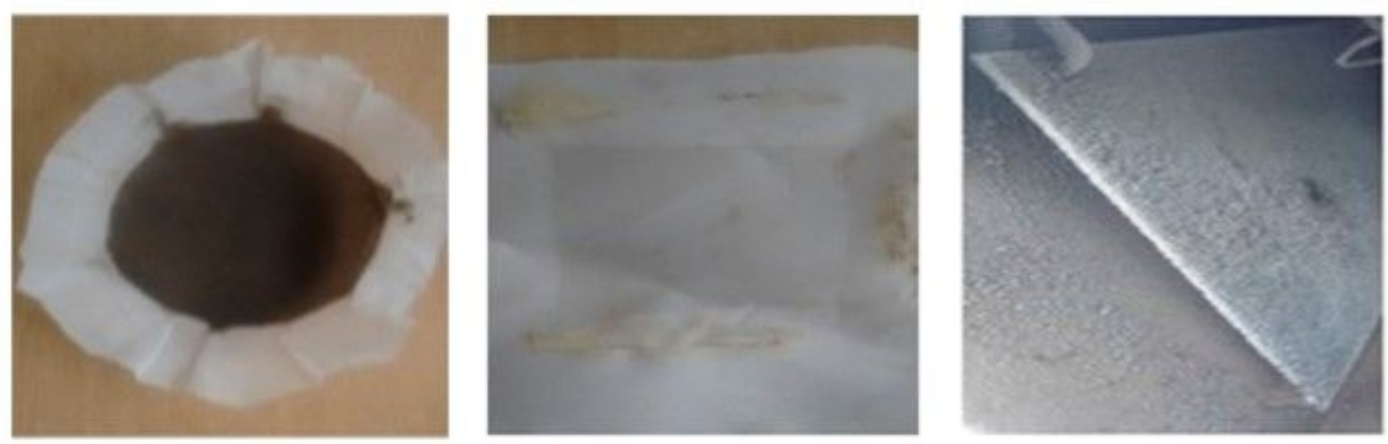

(a)

(b)

(c)

\section{Figure 8}

(a, b)Polyester Filter Samples before and after the ESP, (c)Collecting plate after gas treatment in ESP 